Www.jmscr.igmpublication.org

Index Copernicus Value: 79.54

ISSN (e)-2347-176x ISSN (p) 2455-0450

crossrefDOI: https://dx.doi.org/10.18535/jmscr/v7i3.27

\title{
The Effects of Effleurage Massage and Abdominal Lifting Massage to Reduce Pain in the First Stage of Labor Process
}

\author{
Authors \\ Risneni $^{1^{*}}$, Riyanti Imron ${ }^{2}$ \\ ${ }^{1,2}$ Department of Midwifery, Health Polytechnic of Tanjungkarang, Indonesia \\ *Corresponding Author \\ Risneni \\ Email: riyantiimron74@gmail.com
}

\begin{abstract}
Background: Labor is often associated with pain, especially during the first stage. Good labor management is shown by the labor process that does not last too long and is accompanied by a tolerable level of pain. One of the effective methods in dealing with labor pain is to provide non-pharmacological actions, such as performing effleurage massage and abdominal lifting massage which are used to overcome labor pain at the time of the first stage and active phase because it causes a relaxation reaction.

Objective: The purpose of this study was to find out the effect of effleurage massage and abdominal lifting massage to reduce pain in the first stage of labor process in the independent midwife clinics in South Lampung Regency, Indonesia.

Method: The type of research used was experimental research. The research design was true experimental with pre and post-test only design. The population in this study were all mothers who were in the first stage of normal labor in the independent midwife clinics in South Lampung Regency. Sixty samples were divided into 3 groups where 20 respondents received intervention on massage effleurage, 20 respondents received intervention on abdominal lifting massage, and the rest were the control group. The data obtained were then analyzed using the Wilcoxon, Mann Whitney, and Kruskal-Wallistests.

Result: The results showed that the highest reduction in the average pain scale of the labor process was in the effleurage massage treatment, namely from the pain scale of 5.55 to 3.75. Based on the results of the Kruskal-Wallis test, the obtained $\alpha$ was 0.000. This means that there was a significant difference between effleurage massage compared to abdominal lifting massage in reducing pain in the first stage of the labor process.
\end{abstract}

Conclusion: Effleurage massage treatment was more effective in reducing pain in the first stage of the labor process.

Keywords: Abdominal Lifting, Effleurage, Labor, Massage, Pain.

\section{Introduction}

Labor is often associated with the pain that will be experienced by mothers. Pain at first stage of labor is a physiological process caused by cervical dilatation, uterine muscle hypoxia during contraction, ischemia of the uterine body and stretching of the lower uterine segment, and nerve compression in the cervix (Bandiyah, 2009). 
Reported from 2700 maternity mothers, only $15 \%$ of deliveries took place with mild pain, $35 \%$ with moderate pain, $30 \%$ with severe pain, and $20 \%$ of labor accompanied by very severe pain (Rejeki and Nurullita, 2013).

Good labor management is shown by the labor process that does not last too long and is accompanied by a tolerable level of pain. One of the effective methods in dealing with labor pain is to provide non-pharmacological actions, such as performing effleurage massage and abdominal lifting massage which are used to overcome labor pain at the time of the first stage and active phase because it causes a relaxation reaction. Effleurage massage is the administration of cutaneous stimulation which is almost similar to the act of giving aromatherapy, hypnosis, acupuncture, and yoga (Handayani, 2016).

Based on the results of the survey in South Lampung Regency in January 2018, there were 985 maternity mothers in 56 independent midwife clinics. The practice of independent midwife clinics in South Lampung Regency has yet to carry out interventions for relaxation techniques of effleurage massage or abdominal lifting massage in the treatment of labor pain. Based on this issue, the authors were interested in conducting a study with the purpose of finding out the effect of effleurage massage and abdominal lifting massage to reduce pain in the first stage of labor process in the independent midwife clinics in South Lampung Regency, Indonesia.

\section{Materials and Methods}

The type of research used was experimental research. The research design was true experimental with pre and post-test only design. The population in this study were all mothers who were in the first stage of normal labor in the independent midwife clinics in South Lampung Regency. Sixty samples were divided into 3 groups where 20 respondents received intervention on massage effleurage, 20 respondents received intervention on abdominal lifting massage, and the rest were the control group. The data obtained were then analyzed using the Wilcoxon, Mann Whitney, and KruskalWallis tests.

\section{Results and Discussion}

Figure 1 shows the pain levels perceived by maternity mothers. From Figure 1, it can be seen that prior to the treatment of massage intervention, the most dominant labor pain felt by 60 respondents was medium scale (4-6), that was as many as 46 respondents $(85 \%)$.

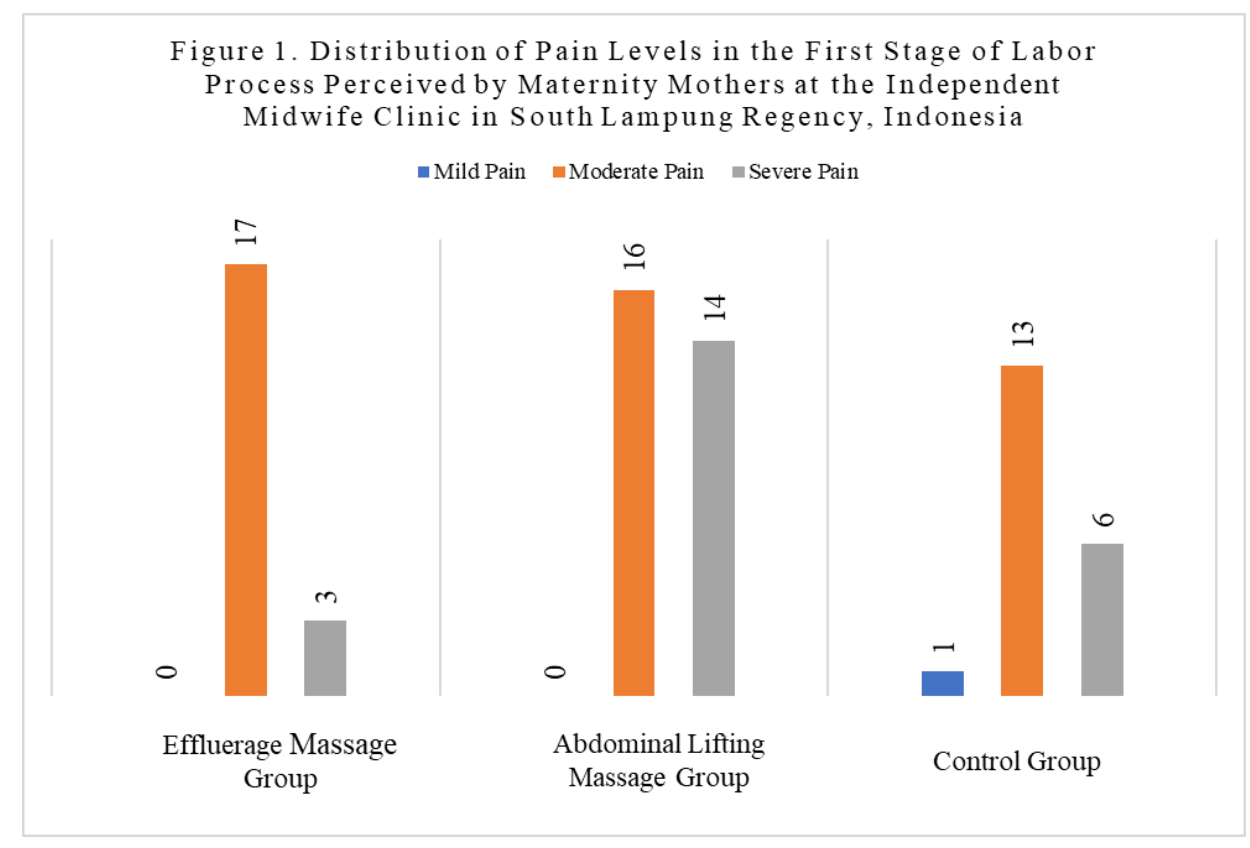




\section{JMSCR Vol||07||Issue ||03||Page 140-144||March}

Table 1 shows the average level of pain in the first stage of the labor process experienced by respondents who were given the treatment of effleurage massage. From Table 1, it can be seen that there was a reduction in the level of pain. The initial pain scale was 5.55 and at the end of the treatment, it reduced to 3.75 .

Table 1 The Average Level of Pain in the First Stage of Labor Process Perceived by Respondents of Effleurage Massage Group

\begin{tabular}{|l|c|c|c|c|}
\hline Variable & Mean & $\begin{array}{c}\text { Standard } \\
\text { Deviation }\end{array}$ & $\begin{array}{c}\text { Minimum Pain } \\
\text { Level }\end{array}$ & $\begin{array}{c}\text { Maximum } \\
\text { Pain Level }\end{array}$ \\
\hline Initial Condition & 5.55 & 1.050 & 4 & 8 \\
\hline $\begin{array}{l}\text { After Effleurage } \\
\text { Massage Treatment }\end{array}$ & 3.75 & 1.020 & 2 & 6 \\
\hline
\end{tabular}

Table 2 shows the average level of pain in the first stage of the labor process experienced by respondents who were given the treatment of abdominal lifting massage. There was also a reduction in the level of pain in this treatment group, however, the reduction was smaller than the effleurage massage group. The initial pain in this group was 5.55 and at the end of the treatment, it reduced to 3.95 .

Table 2 The Average Level of Pain in the First Stage of Labor Process Perceived by Respondents of Abdominal Lifting Massage Group

\begin{tabular}{|l|c|c|c|c|}
\hline Variable & Mean & $\begin{array}{c}\text { Sstandard } \\
\text { Deviation }\end{array}$ & Minimum Pain Level & $\begin{array}{c}\text { Maximum Pain } \\
\text { Level }\end{array}$ \\
\hline Initial Condition & 5.55 & 1.099 & 4 & 8 \\
\hline $\begin{array}{l}\text { After Abdominal Lifting Massage } \\
\text { Treatment }\end{array}$ & 3.95 & 0.945 & 3 & 6 \\
\hline
\end{tabular}

Table 3 shows the average level of painin the first stage of the labor process experienced by control group. Table 3 The Average Level of Pain in the First Stage of Labor Process Perceived by Control Group

\begin{tabular}{|l|c|c|c|c|}
\hline Variable & Mean & $\begin{array}{c}\text { Sstandard } \\
\text { Deviation }\end{array}$ & Minimum Pain Level & $\begin{array}{c}\text { Maximum Pain } \\
\text { Level }\end{array}$ \\
\hline Control Group & 5.95 & 1.356 & 3 & 8 \\
\hline
\end{tabular}

\section{Bivariate Analysis}

Table 4 shows the results of the normality test. Based on Table 4, the data of the abdominal lifting massage group were proven to be distributed abnormally. With abnormal data, then the hypothesis testing was continued by using the Wilcoxon Signed Test to find out whether there were differences before and after treatment.

Table 4 Normality Test Results Before and After the Massage Treatment

\begin{tabular}{|c|c|c|c|}
\hline Variable & Mean & $\begin{array}{l}\text { Standard } \\
\text { Deviation }\end{array}$ & $\begin{array}{c}\text { Asymp. Sig. (2- } \\
\text { tailed) }\end{array}$ \\
\hline BeforeEffleurage Massage Treatment & 5.55 & 1.050 & 0.035 \\
\hline After Effleurage Massage Treatment & 5.75 & 1.020 & 0.001 \\
\hline Before Abdominal Lifting Massage Treatment & 5.55 & 1.099 & 0.003 \\
\hline After Abdominal Lifting Massage Treatment & 3.95 & 0.945 & 0.003 \\
\hline
\end{tabular}

Table 5 shows the results of the Wilcoxon Signed Rank test. The results showed that there was a significant difference in the level of pain before and after massage treatment. Both effleurage massage and abdominal lifting massage had an effect to reduce pain in the first stage of labor 
process perceived by maternity mothers in the independent midwife clinics in South Lampung
Regency, Indonesia.

Table 5 Wilcoxon Signed Rank Test Results

\begin{tabular}{|l|c|c|c|c|c|c|c|}
\hline Level of Pain & $\mathbf{N}$ & $\begin{array}{c}\text { Negative } \\
\text { Rank }\end{array}$ & $\begin{array}{c}\text { Positive } \\
\text { Rank }\end{array}$ & Ties & $\begin{array}{c}\text { Sum of } \\
\text { Ranks }\end{array}$ & $\mathbf{z}$ & $\begin{array}{c}\text { Asymp. Sig } \\
\text { (2-tailed) }\end{array}$ \\
\hline $\begin{array}{l}\text { Before and After Effleurage } \\
\text { Massage Treatment }\end{array}$ & 20 & 20 & 0 & 0 & 210 & -3.895 & 0.000 \\
\hline $\begin{array}{l}\text { Before and After Abdominal } \\
\text { Lifting Massage Treatment }\end{array}$ & 20 & 19 & 0 & 1 & 190 & -3.982 & 0.000 \\
\hline
\end{tabular}

Table 6 shows the results of the Mann Whitney test and Table 7 shows the results of the KruskalWallis test. Based on the results on Table 6 , the $\alpha$ value was 0.529 so that $\alpha>0.05$, which means that $\mathrm{HO}$ was rejected and thus there was no significant difference between massage effleurage and massage abdominal lifting to reduce first stage labor pain. The data were then analyzed using the
Kruskal-Wallis test. The test resulted in $\alpha$ value of 0.000 so that $\alpha<0.05$, which means there were significant differences between the effleurage massage, abdominal lifting massage, and the control groups. The most effective result of reducing pain in the first stage of labor is effleurage massage treatment.

Table 6 Mann Whitney Test Results

\begin{tabular}{|l|c|c|c|}
\hline Variable & N & $\begin{array}{c}\text { Mean } \\
\text { Rank }\end{array}$ & $\begin{array}{c}\text { Asymp. } \\
\text { Sig. }\end{array}$ \\
\cline { 1 - 3 } Effleurage Massage Treatment & 20 & 21.68 & \multirow{2}{*}{0.529} \\
\hline Abdominal Lifting Massage Treatment & 20 & 19.33 & \\
\hline
\end{tabular}

Effleurage massage can reduce pain effectively because it provides relaxation and relief of pain, especially when it is applied directly on the body surface which is not being covered by clothing (Wulandariand Hiba, 2015). Effleurage massage is light and rhythmic massage technique which applies light massage on the back, waist, abdomen, or thigh (Field et al., 2010). Effleurage massage technique is capable of relaxing the spinal muscles which link the brain and the peripheral nervous system (Anderson and Maes, 2013). Due to this mechanism, the levels of cortisol hormone decreases and thus maternity mothers will feel more relaxed (Sarliand Agus, 2014).

Table 7 Kruskal-Wallis Test Results

\begin{tabular}{|l|c|c|c|}
\hline Variable & N & $\begin{array}{c}\text { Mean } \\
\text { Rank }\end{array}$ & $\begin{array}{c}\text { Asymp. } \\
\text { Sig. }\end{array}$ \\
\hline Effleurage Massage Treatment & 20 & 21.45 & \multirow{2}{*}{0.000} \\
\cline { 1 - 3 } Abdominal Lifting Massage Treatment & 20 & 24.10 & \multirow{2}{*}{0.00} \\
\cline { 1 - 2 } Control Group & 20 & 45.95 & \\
\hline
\end{tabular}

\section{Conclusion}

There was a significant difference with $\alpha$ value of 0.000 between effleurage massage compared to abdominal lifting massage in reducing pain in the first stage of the labor process. Effleurage and abdominal lifting massages were capable to reduce the pain level from 5.55 to 3.75 and from
5.55 to 3.95 , respectively. Based on the results and analyzed data, it can be concluded that effleurage massage treatment was more effective in reducing pain in the first stage of the labor process. 


\section{References}

1. Anderson, G., \& Maes, M. 2013. Postpartum depression: Psychoneuroimmunological Underpinnings and Treatment. Neuropsychiatric Disease and Treatment Vol.9, pp.277-287.

2. Bandiyah, S. 2009. Lanjut Usiadan Keperawatan Gerontik. Yogyakarta: Nuha Medika

3. Field, T., Deeds, O., Diego, M., Hernandez-reif, M., Gauler, A., Sullivan, S., Nearing, G. 2010. Benefits of Combining Massage Therapy with Group Interpersonal Psychotherapy in Prenatally Depressed Women, Journal of Bodywork and Movement TherapiesVol. 13, No. 4, pp. 297-303.

4. Handayani, S. 2016. Effleurage Massage Effect Toward the Birth Pain in Level 1 Of Active Phase in Treatment. Jurnal Kesehatan SamodraI lmu Vol. 07, No. 02, pp. 1-11.

5. Rejeki, S. and Nurullita, U. 2013.Tingkat Nyeri Pinggang Kala I Persalinan Melaluiteknik Back-Efflueragedan Counter Pressure. Jurnal Keperawatan Maternitas, Vol. 1, No. 2, pp. 124-33.

6. Sarli, D., \&Agus, M. 2014. Research Articles the Effect of Differences Oxytocin Levels Through Oxytocin Massage Against Number of Bleeding in Mother 2 Hours Postpartum. Jurnal Kesehatan Andalas Vol. 4, No. 3, pp. 743-750.

7. Wulandari and Hiba.2015. Pengaruh Massage Effleurage Terhadap Pengurangan Tingkat Nyeri Persalinan Kala I Fase Aktif Pada Primigravida di Ruang Bougenville RSUD Tugurejo Semarang. Journal Maternity Nursing Vol. 3, No.(1), pp. 59-67. 